\title{
INDONESIA STATISTIK: SURAT BUAT PARA PEMBACA
}

\section{Benedict R. O'G. Anderson}

"Saya dari dulu tidak setuju, koq..." dari lapisan bawah. "Gue pernah bilang ama Pak Harto lho! ..." dari lapisan atas. Memang, menjemukan dan menjijikan kalau keluar dari mulut orang lain, tetapi kalau meluncur dari bibir kita sendiri betapa serius dan meyakinkan. Begitulah, agaknya, isi hati nurani "kelas menengah" Indonesia (lebih tepat Jakarta) yang selama ini banyak diharapkan oleh kaum intelek baik didalam maupun diluar negeri.

Pada zaman baheula, kelas menengah ini suka disebut sebagai "borjuasi nasional," dan dianggap mempunyai misi historis baik sebagai borjuasi maupun sebagai nasionalis. Anggapan ini pada mulanya bukan ilusi melulu. Kita tahu bahwa sebagian besar dari tokoh pergerakan, yang cukup bernyali untuk masuk bui, diasingkan ke Tanah Merah, Banda, atawa Flores, dan mengorbankan dompet maupun karir demi kemerdekaan, muncul dari lapisan menengah dari masyarakat kolonial. Mereka duduk di ruang tengah antara penguasa bule dan jutaan petani, buruh, lonte, tukang, dan babu. Sampai sekarang nama2 seperti Sutan Sjahrir, Ibrahim Datuk Tan Malaka, Ir. Sukarno, Natsir, Semaun, Drs. M. Hatta, Soewarsih Djojopoespito, Mr. Raden Mas Sartono, Alimin, Trimurti, Haji Misbach, Armijn Pane dan sebagainya lumayan harum.

Tetapi: tentunya tidak semuanya begitu. Kita ingat tokoh Sastro Kassier dalam roman Anak Semua Bangsa. Kata Pramoedya: "Tapi jabatan: dia segala dan semua bagi Pribumi bukan tani dan bukan tukang. Harta-benda boleh punah, keluarga boleh hancur, nama boleh rusak, jabatan harus selamat.... Orang berkelahi, berdoa, bertirakat, memfitnah, membohong, membanting tulang, mencelakakan sesama, demi sang jabatan. Orang bersedia kehilangan apa saja untuk dia, karena, juga dengan dialah segalanya bisa ditembus kembali." Pada dasawarsa terakhir zaman Belanda $90 \%$ dari birokrasi kolonial, yang jumlahnya 250,000 doang, adalah pribumi. Anggaplah 225,000 sosok manusia-jauh diatas jumlah orang2 pergerakan pada 
174 Benedict R. O'G. Anderson

ketika itu. Lantas Jepang masuk. Apa yang terdengar? "Saya dari dulu tak setuju dengan Belanda koq..." Dan massa Sastro2 ini bergegas 2 pindah menjadi pegawainya Balatentara Dai Nippon. Sejarah selanjutnya hampir sama. "Saya dari dulu tidak setuju dengan Jepang yang buas/Demokrasi Barat yang keblinger/Orde Lama yang kacau/Orde Kropos yang korup, koq!" Jarang ada diantaranya yang minta berhenti dari jabatannya pada tingkat apapun juga. Lebih jarang lagi yang mengaku berdosa, bersedia bertanggungjawab. ('Kan, yang salah Suharto, Islam fanatik, Sukarno, Belanda, CIA, Keristen, Komunis, Cina brengsek....) Dan jumblah mereka membubung terus bagaikan cendawan dalam musim hujan yang tak pernah diganti musim kemarau yang sehat.

Tapi masalahnya bukan korps pegawai negeri "segala zaman" melulu. Empatpuluh tahun yang lalu si Mat Hitam yang malang, Frantz Fanon, sudah menulis bahwa sebagian besar dari pribumi2 yang menjadi doktor, advokat, pedagang, pengusaha kecil, dan sebagainya, aspirasinya hanya "mengisi sepatunya" tuan2 kolonial pada suatu hari yang menyenangkan. Selanjutnya: "kelas menengah nasional lantas menemukan misi historisnya: menjadi belantik" antara kapitalisme internasional dan rakyat. Hukumannya Fanon yang terakhir: "Kelas menengah ini sudah pikun tanpa pernah mengalami masa mudabelia dengan keberanian, kenekadan, dan semangat perintisnya."

Memang, Van Diemen, Cortes, dan Vasco da Gama adalah bajingan, tetapi mereka berani menjelajahi setiap samudera mencari penemuan baru pada masa kemungkinan mati diperjalanan masih tinggi. Orang borjuis bangsanya Galileo, Newton, Faraday, Pasteur, Rousseau dllnya mengubah pikiran manusia secara mendalam atas dasar penemuannya. Apalagi penulis2, pelukis2, arsiktek2, dan sekian lainnya. Warisan mereka adalah suatu tantangan: kalau borjuis, silahkan menjadi borjuis yang berani, pingintahu, dan berdarah muda, biarpun sama sekali bukan orang suci. Janganlah menjadi cuman borjuis penakut, mlempem, dan bermental belantik.

Nasionalismepun muncul didunia seirama dengan perubahan pikiran manusia secara mendasar tadi, permulaan revolusi industri, dan naiknya "kelas menengah" kearah puncak kekuasaan atas puingnya rezim2 feodal-absolut. Dan nasionalisme untuk mereka (juga untuk Sukarno, Hatta cs) adalah panggilan untuk bertindak, bukanlah sesuatu yang alamiah seperti warna kulit, bentuk mata, dan jenis kelamin. Mereka lihat kedepan, bukan kebelakang. Dan karena itu mereka kreatip. Sama sekali bukan "pikun." Mereka juga merobohkan sistim politik lama berdasarkan kasta bangsawan macam "trah ing kusuma" yang menjengkelkan, yang merasa diri berhak berkuasa atas dasar silsilah. Akhir kata, mereka mengerti bahwa si jabangbayi bisa saja dicatat sebagai seorang Mesir, Norwegia atawa Indonesia, tetapi itu cuman diatas kertas. Dalam kasus Indonesia, si kecil baru akan menjadi orang Indonesia kalau belajar mencintai sesama bangsanya dan berani berkorban untuknya. Dan kalau "keseleo," dia mungkin akan menjadi "orang Indonesia statistik," yaitu "orang Indonesia-kalau-perlu-dan-ada-rejekinya."

Masalah sekarang, hampir 55 tahun setelah Indonesia menjadi merdeka, adalah sampai kemana kelas menengah di Jakarta sudah menjadi "Indonesia-statistik" dan "Indonesia kalau perlu." Apakah kelas ini masih bisa dilndonesiakan kembali, dan melepaskan diri dari kepikunan yang sudah sangat parah? Jadi masalahnya mental dan tekad. Menganggap diri anggota oposisi dengan tetap bicara tentang "Pak" Harto, 
"Bu" Tien dan "Mbak" Tutut; angguk2 kepala ketika seorang presiden Republik (Indonesia) seenaknya bergumam tentang lengser ke-prabu-annya; marah karena bule ribut masalah pelanggaran HAM di bekas TimTim, Aceh, dan Irian Barat (seorang bekas menteri barusan dengan jengkel mengatakan 'mereka tidak mengerti bahwa di Jakarta tidak ada orang peduli pada Timtim, Irian, dan Aceh'), dan lebih marah lagi karena "dana" bule keparat koq tidak datang2; merasa tersinggung kalau babunya tidak menjongkok didepan kakinya; dan lebih takut pada rakyat daripada polisi dan "lalat ijo"-sikap "pikun" macam ini sangat meluas selama Orde Kropos.

Sebaliknya tanda kreativitas mungkin terasa tidak banyak-dibidang politik, ekonomi, sosial, dan kebudayaan. Betapa norak roman muka Jakarta, dan betapa miskin dalam hal2 yang bisa dikagumi. Kelas menengah Jakarta belum mampu mendirikan suatu "dunia orisinil." Mereka masih sibuk "mengkonsumsikan" apa saja dari luar biarpun dibumbui sana-sini dengan "kliping2" dari kebudayaan nenekmoyang masing2. Mungkin masalahnya karena mereka merasa diri "otomatis" orang Indonesia, seolah2 kalau beli Mercy, Mercy itu dengan demikian menjadisimsalabim-barang Indonesia.

Menjadi seorang keturunan Tionghoa di Indonesia bukanlah sesuatu yang menggembirakan. Kita tahu betul bagaimana selama Orde Kropos, kebudayaan mereka diinjak dan hak berkesempatan menjadi teknokrat maling, jendral buas, rektor plinplan, dsbnya ditiadakan. Emangnya karena mereka bukan "otomatis" Indonesia. Anehnya hal yang menyedihkan ini sekali2 bisa memberi berkah. Ada diantaranya yang secara sangat sadar mengetahui bahwa mereka harus berbuat untuk menjadi "Indonesia," malahan "warga negara Indonesia" (seolah2 pribumi tak perlu menjadi warga negara!). Selama kira2 duapuluh lima tahun belakangan ini, saya biasa tanya pada anak2 muda dari Indonesia yang kebetulan singgah atau menetap di Universitas Cornell: Bung kagum sama siapa saja di Indonesia? Sering mereka kewalahan, tidak bisa jawab (kalau pembaca yang tercinta masih tidak percaya bahwa Orde Baru itu kropos, atau kelas menengah di Jakarta tidaklah pikun, inilah barang buktinya!). Tetapi kalau ada jawaban, sering nongol nama2 orang keturunan Tionghoa: Yap Thiam Hing, advokat ulung yang tak terbeli dan tak bisa dibikin takut; Dede Oetomo, yang berani buka diri sebagai seorang homosex, dan sekaligus berusaha keras untuk melawan malapetaka AIDS dan membantu sesama gay dan banci, tidak peduli pribumi atawa keturunan Tionghoa; Arief Budiman, yang sejak awal tahun 70-an menyusul jejak adiknya Soe Hoe Gie almarhum sebagai pengritik terbuka terhadap politik dan immoralitasnya "Pak" Harto; atau Riantiarno, yang tanpa genitnya Rendra yang menjemukan itu, berusaha membangun teater borjuis yang orisinil dan tajam dikota metropolitan.

Mungkin inilah jalan keluar: Sastro Kassier harus belajar menjadi WNI, warga negara dari suatu Republik yang namanya Republik Indonesia, bukannya seorang "Indonesia otomatis" yang merangkak dilantainya suatu keprabon yang akhirnya selalu akan terlengserkan.

Para pembaca Tempo: Hallo????.....Hallo???... Bangun belum??? 
